ja diskurssina. Acta Universitatis Tamperensis 910. Tampere: Tampere University Press.

Rintala, Päıvi 1998: Kielikäsitys ja kielenohjailu. - Sananjalka 40 s. 47-64.

Sajava ara, Paula 2000: Kielenohjailu.

- Kari Sajavaara \& Arja Piirainen-

Marsh (toim.), Kieli, diskurssi \&

yhteisö s. 67-106. Jyväskylä: Jyväskylän

yliopisto, Soveltavan kielentutkimuksen keskus.
VaAttovaAra, Johanna 2009: Meän tapa puhua. Tornionlaakso pellolaisnuorten subjektiivisena paikkana ja murrealueena. Helsinki: Suomalaisen Kirjallisuuden Seura.

Vinikainen, TARU 2010: Taipuuko "akrobaatti Aleksandra"? Nimikekonstruktio ja nimikkeen taipuminen lehtikielessä 1900-luvulta 200o-luvulle. Joensuu: ItäSuomen yliopisto.

\title{
Kattava kuvaus itämerensuomen balttilaislainoista
}

\author{
Santeri Junttila: Tiedon kumuloituminen \\ ja trendit lainasanatutkimuksessa. Kanta- \\ suomen balttilaislainojen tutkimushistoria. \\ Helsinki: Helsingin yliopisto 2015. $291 \mathrm{~s}$. \\ ISBN 978-951-1841-7.
}

Itämerensuomalaisten ja balttilaisten kielten yhteisistä sanoista on tehty havaintoja jo ennen nykyaikaisen kielitieteen syntyä, mutta vasta $1800-$ luvulla pystyttiin kehittämään metodit, joiden avulla havaittujen yhtäläisyyksien laatua voitiin arvioida ja täsmentää. Uranuurtaja oli tanskalainen Vilhelm Thomsen, jonka klassinen teos Beröringer mellem de finske og de baltiske (litauisk-lettiske) Sprog: En sproghistorisk Undersøgelse ilmestyi Kööpenhaminassa vuonna 1890. Jo parikymmentä vuotta aiemmin Thomsen oli julkaissut vastaavan esityksen germaanisista lainoista (Thomsen 1870), joiden yhteydessä hän otti kantaa myös muutamiin balttilaisperäisiin sanoihin sekä kielikontakteihin yleisemmin. Kielellisen substanssin äkillisen karttumisen ohella ratkaiseva edistysaskel oli äännehistoriallinen kehys ja täsmällinen analyysimenetelmä, jolla Thomsen käsitteli aineistoaan. Työstä tuli esikuva ja lähtökohta itämerensuomalaiselle lainasana- tutkimukselle. Santeri Junttila on väitöskirjassaan selvittänyt, mitä kansainvälinen tiedeyhteisö Thomsenista alkaen on saanut aikaan balttilaislainojen tutkimuksen alalla vuoteen 2009 mennessä. Tutkimuksen aineistona ovat kaikki ne itämerensuomalaiset sanat, joille on vähintään kerran ehdotettu balttilaista lainaetymologiaa.

\section{Väitöskirjan rakenne}

Junttila on jakanut väitöskirjansa viiteen päälukuun. Näistä ensimmäinen on johdanto, jossa selostetaan työn tavoitteet, aiemman tutkimuksen pääkohdat, aineiston rajaukset sekä esitystavat ja työn rakenne. Toisessa luvussa määritellään, mitä tarkoittavat kantasuomi, balttilaisuus ja lainaetymologia. Lisäksi selvitetään, miten lainaetymologioiden määrä on tutkimuksessa laskettu. Se on olennaista työssä, jossa kvantitatiivisilla seikoilla on keskeinen osuus.

Luvussa 3 esitellään aineiston balttilaiset lainaetymologiat sekä niiden saama vastaanotto tiedeyhteisössä. Ensin tarkastellaan alkuperämainintojen tyyppejä. Junttila tähdentää, että pelkkä väite sanan balttilaisesta alkuperästä ei vielä tee siitä 
lainaetymologiaa vaan lisäksi tarvitaan uskottava rinnastus lähtömuotoa edustavaan sanaan. Yleistajuisissa katsauksissa lainasanat esitetään usein yksinkertaisina luetteloina vailla rinnastuksia ja perusteluja, ja tästä saattaa asiaa tarkemmin tuntemattomille syntyä sellainen harhakuva, että uusienkin etymologioiden esittäminen on vain pintapuolista luettelemista.

Tiedeyhteisön kommentit etymologioita koskevissa keskusteluissa ovat kiinnostavia, koska niiden kautta muodostuu sanan etymologinen status. Tämä keskustelu käydään tutkijayhteisön piirissä alan konferensseissa ja tutkimuskirjallisuudessa argumentein, jotka yleensä avautuvat vain alaan perehtyneille. Keskustelun analysoinnin pohjalta Junttila jaottelee aineistonsa etymologiat keskeytyksittä hyväksyttyihin (A), keskustelun myötä hyväksyttyihin (B), kiistanalaisiin (C), kannatuksensa menettäneisiin (D), kritisoituihin ja kannatuksettomiin (E), maininnatta hylättyihin (F) ja arvioimattomiin (G). Luvun 3 päätteeksi hän summaa trendejä, joita etymologioiden vastaanotossa on eri aikoina ollut havaittavissa.

Luvussa 4 Junttila erittelee argumentteja, joita etymologioiden perustelussa tai kumoamisessa on käytetty. Hän esittelee viisi eri argumenttityyppiä: muoto-, merkitys-, lähtökieli-, levikki- ja lainakerrostuma-argumentit. Kunkin tyypin alalajeja käsitellään omissa alaluvuissaan. Luku 4 on työn laajin.

Luvussa 5 Junttila kokoaa työnsä tulokset. Hän erottaa tutkimassaan 141 vuoden mittaisessa jaksossa kolme kautta. Ensimmäistä edustaa Thomsenin ajan kukoistusvaihe 180o-luvun jälkipuoliskolla. Sitä seuraa vakiintuneisuuden kausi, jolloin lainasanatutkimus jää taka-alalle vanhan perintösanaston tutkimuksen rinnalla. Tilanne jatkuu 1970-luvun alkuun asti, jolloin tapahtuu tutkimusparadigman muutos nuorgrammaattisesta strukturalistiseksi ja alkaa lainasanatutkimuksen uusi nousu. Lopuksi Junttila hylkää muu- tamia aiemmin hyväksyttyjä balttilaisetymologioita (mm. karsina, huoli) ja arvioi mahdollisesti oikeiksi eräitä sellaisia selityksiä, jotka muu tiedeyhteisö on ollut taipuvainen hylkäämään ( $\mathrm{mm}$. sulhanen, teeri).

\section{Oma etymologinen kirjasto}

Junttilan tutkimusaihe on poikkeuksellisen haastava, koska itämerensuomen balttilaisia lainoja ovat tutkineet muutkin kuin suomensukuisten kielten spesialistit eikä tieteellinen vuoropuhelu kielikuntarajan yli ole ollut kovinkaan aktiivista (ks. s. 135). Tuloksia on julkaistu monilla eri kielillä ja useilla sellaisillakin foorumeilla, jotka eivät ole fennougristi- tai fennistipiireissä yleisesti tunnettuja. Junttila on jäljittänyt lähteitä etymologisista viitetaulukoista, kortistoista, hakemistoista, tutkimuskirjallisuudesta sekä kirjastoväkeä ja kollegoita konsultoimalla.

Lähteiden hankkiminen omaan käyttöön on ollut monen vuoden projekti. Junttila on itse koonnut skannaamalla ja valokuvaamalla etymologisen kirjaston, johon hän on tallentanut työnsä kannalta relevantit tutkimustekstit. Esipuheessa hän toteaa, että vain pieni osa aineistosta on saatavilla Internetissä. Digitaalisten aineistojen tilanne paranee koko ajan, mutta fennougristiikka ei edusta kehityksen terävintä kärkeä. Sivulla 38 Junttila toteaa sarkastisesti, että nykyinen kulutus-Suomi käyttää kielellisen menneisyytensä kartoittamiseen paljon vähemmän varoja kuin Setälän ajan köyhä agraari-Suomi.

\section{Rajauksia}

Alkuperäisen suunnitelman mukaan Junttilan väitöskirjaan olisi sisältynyt laaja kronologinen katsaus tutkimuksen edistymiseen Thomsenin päivistä nykyaikaan asti. Se on kuitenkin jätetty pois, koska työn sivumäärä uhkasi paisua yli ihanne- 
mittojen. Sen asemesta työn alussa on tiivis katsaus aiempaan tutkimukseen. Tutkimuksen edistymiseen liittyviä tietoja on käytetty aineksina eri argumenttien käyttöä koskevissa luvuissa 4.3-4.7.

Junttila on rajannut työstään pois monia sellaisia osa-alueita, joita usein on pidetty lainasanatutkimuksen kiinnostavimpana antina. Hän ei käsittele lainakontaktien aikaa eikä paikkaa. Hän ei myöskään esitä sana-aineistoaan aihepiirien mukaisesti jaoteltuna, niin kuin usein tehdään pohdittaessa lainojen kulttuurihistoriallista todistusvoimaa. Merkityksiä hän käsittelee niiltä osin, kuin niitä on käytetty etymologisen päättelyn perustana. Aihepiirit tulevat joiltakin osin esiin tarkasteltaessa niitä merkityksiin perustuvia argumentteja, joita lainaetymologioiden tueksi tai kumoamiseksi on esitetty.

Sanojen merkitykset on poimittu sanakirjoista, ja kieli vaihtelee lähteen mukaan (ks. tarkemmin lukua 1.4). Lukijalta vaaditaan monen kielen taitoa ja kykyä huomata itse, mikä kieli milloinkin on kysymyksessä. Muinaisslaavin sanojen merkitykset on kuitenkin jätetty pois, koska käytetyssä sanakirjassa ne olisivat olleet vain kreikaksi, tšekiksi ja venäjäksi. Slaavilaisissa esimerkkisanoissa käytetty fontti sulautuu muuhun tekstiin, joten se erottuu selvästi vain silloin, kun sanoissa on kyrilliselle kirjaimistolle ominaisia merkkejä.

Lukijan kannalta olisi ollut hyödyksi, jos Junttila olisi esitellyt eksplisiittisesti sekä kantabaltin että kantasuomen äännejärjestelmät ja niitä koskevissa käsityksissä tapahtuneet tärkeimmät muutokset tutkimusjakson ajalta. Nyt esiin nousevat lähinnä ne äänteet ja äänteenmuutokset, jotka tarjoavat kriteerejä lainasuhdetta koskevassa argumentoinnissa. Thomsenin luettelon tiivistelmä balttilaiskielten äänteiden itämerensuomalaisista vastineista on alaluvussa 4.3.1.2, mutta siinä ei ole kysymys kantakielten rekonstruktiotasosta muutamia yksittäisiä äänteitä lukuun ottamatta.

\section{Ei yleistä teoriaa}

Junttilan väitöskirja on vahvasti aineistolähtöinen ja empiirinen. Päätelmät nousevat aineistoa koskevista havainnoista ja laskelmista. Tieteenfilosofit ovat kuitenkin jo kauan sitten todenneet, ettei tiede ole pelkkää teorianeutraalien faktojen keräämistä eikä teoriaa ja empiriaa voi erottaa toisistaan. Tieteellisen tiedon kasvua on kuvattu monin tavoin, joista esimerkiksi Thomas Kuhnin (1970) klassista paradigmamallia on sovellettu 1900-luvun fennistiikkaankin (ks. Karlsson 1975). Myös Junttilan työssä tulee esiin se, kuinka taustalla vaikuttavan teoreettisen ajattelun muuttuminen vaikuttaa havaintojen tulkintaan, esimerkiksi silloin, kun käsitykset äännehistoriasta, kielen järjestelmäluonteesta tai kantakielten keskinäisistä suhteista ovat muuttuneet tai muuttumassa (esim. s. 49, 208-213, 241), mutta tätä ei ole teoksessa nostettu näkyviin teorian tasolla. Karl Popper mainitaan ohimennen sivulla 97, mutta ilman lähdeviitteitä.

Tieteenteoria tarjoaisi aseita monen muunkin relevantin ongelman käsittelyyn. Kuinka monta havaintoa tarvitaan hypoteesin verifioimiseen tai kumoamiseen? Milloin ja miten teoriaa voi korjata ja milloin se on hylättävä? Ovatko nykyetymologiat laadullisesti parempia kuin Thomsenin etymologiat vai ovatko ne vain erilaisia? Johdannon alkuluvussa Junttila puhuu paradigmojen vaihtumisesta, mutta ei kytke tätä mihinkään teoreettiseen kehykseen.

Junttilan työstä käy ilmi, että balttilaislainoja ovat esittäneet, kannattaneet ja vastustaneet muutkin kuin varsinaiset etymologit, esimerkiksi perinnetieteiden tutkijat. Erityisesti näiden kohdalla herää kysymys, voiko eri alojen edustajien esittämää argumentointia käsitellä samojen kriteerien puitteissa, ja toisaalta, 
voiko ja tarvitseeko kielellistä tietoa erottaa jyrkästi ensyklopedisesta tiedosta, kun sanoilla usein on selvät kytkökset kielenulkoiseen maailmaan. Liettuan sanaa šeškas 'hilleri' käsitellessään Junttila (s. 238) referoi itsekin kielenulkoista tietoa kyseisen eläimen levinneisyydestä.

\section{Sähköinen liite täydentää}

Painettua väitöskirjaa täydentää pelkästään sähköisenä julkaistu taulukkoliite. ${ }^{1}$ Sen ensimmäisessä taulukossa on lueteltu kaikki etymologisesta kirjallisuudesta löytyneet balttilaista alkuperää koskevat maininnat siitä riippumatta, ovatko ne uusia, vanhoja, perusteltuja vai perustelemattomia. Kukin maininta on esitetty omalla rivillään, ja koko tutkimusjakson (vuodet 1869-2009) osalta rivien määrä on peräti 21 251. Taulukon sisällön kvantitatiivista jakaumaa on selostettu teoksen sivulla 63 . Alaluvussa 3.1.2 on graafinen esitys alkuperämainintojen ajallisesta jakaumasta ja alaluvussa 3.1.3 alkuperämainintojen jakautumisesta tutkimuskirjallisuuteen, sanakirjoihin ja yleisteoksiin.

Graafiset esitykset ovat havainnollisia, ja niitä avataan tekstissä kiitettävästi. Sen sijaan liitetaulukon tulkinta on joiltakin osin hankalaa, sillä selitykset on osattava itse hakea joko painetusta tai sähköisestä kirjasta. Joitakin esitystapoja ei selitetä ollenkaan. Sivulla 39 kerrotaan, että tutkimushistoriallisen taulukon ensimmäisenä sarakkeena (A) on alkuperämainintatyypit ja että tyypit määritellään alaluvussa 3.1.1, jossa ei kuitenkaan ole selostettu taulukossa käytettyjä kirjainkoodeja eikä kytketty niitä eksplisiittisesti alkuperämainintatyyppeihin. Merkintätapoja koskevia selityksiä on kirjan eri kohdissa, ja ne saattavat poiketa totutuista. Esimerkiksi lainaetymologian määritelmää käsittelevässä luvussa 2.3 ilmoitetaan, että etymologista

1. Ks. Tutkimushistoriallinen taulukkoliite: https://helda.helsinki.fi/handle/10138/158777. rinnastusta osoitetaan eri tapauksissa merkeillä $\sim$ ja $=$ ja lisäksi lyhenteellä vrt. Myös eräiden kielilyhenteiden kohdalla on mahdollisuus arvata väärin: $l v$ tarkoittaa lättiä eli latviaa ja $v s$ eteläviroa.

\section{Pientä viimeistelemättömyyttä}

Painetussa teoksessa ei ole minkäänlaisia hakemistoja. Jos kirjaa haluaa käyttää tehokkaasti, on pakko turvautua sähköiseen versioon ja etsiä haluamansa sanat hakutoimintojen avulla. Sähköisen liitteen kolmannen taulukon sanalistasta ei ole hakemiston korvaajaksi, sillä siinä on sanat ja termit esitetty sivu kerrallaan aakkostettuina. Siitäkin joutuu siis etsimään sanan eri esiintymät hakutoiminnon avulla. Työn taulukoista ja kaavioista ei ole luetteloa sisällysluettelon yhteydessä. Sivulla 253 viitataan taulukkoon 11, jollaista työssä ei ole.

Lähdeluettelo on runsas, ja vielä lisää on sähköisessä liitteessä, johon on koottu liitteessä esitettyjen mainintojen lähteet. Viittaustekniikkaa ei voi kiitellä yhtenäiseksi. Muutamiin lähteisiin on viitattu teoslyhenteillä, useimpiin normaaleilla tekijän sukunimestä ja vuosiluvusta koostuvilla viittauksilla. Esimerkiksi Thomsenin Beröringer on lyhennetty $B F B$, ja se löytyy lähdeluettelosta $B$-alkuisten kohdalta. Sen sijaan Thomsenin (1870) Über den einfluss der germanischen sprachen auf die finnisch-lappischen löytyy Thomsenin sukunimen kohdalta. Lauri Hakulisen (1979) Suomen kielen rakenne ja kehitys on lähdeluettelossa $S K R K$ ja siis $S$ alkuisten kohdalla. Kun työssä on keskeistä tutkimushistoriallisen tiedon kumuloituminen, olisi tarpeen nähdä kaikkien lähteiden ilmestymisvuodet jo viitteestä.

Kun lähteissä on teoksia, joiden tekijöillä on sama sukunimi, on tapana lisätä viitteeseen etunimen alkukirjain, mutta Junttilan työtä lukeva joutuu lähdeluettelon vuosilukujen perusteella päätte- 
lemään, kuka Häkkinen, Itkonen tai Salminen kulloinkin on kysymyksessä. Timo Salmisen (2008) kohdalla (s. 16) asia ei valkene ollenkaan, koska hänen teoksensa Aatteen tiede puuttuu lähdeluettelosta. Siellä ei ole myöskään yhtään Juha Janhusen teosta, vaikka tällaisiin viitataan esimerkiksi sivuilla 181, 201 ja 253. Myös "Hakulinen 1941" (s. 173, 224) jää arvoitukseksi.

\section{Tyylikäs ulkoasu}

Junttila on taittanut ja painattanut väitöskirjansa itse. Ulkoasu on kielitieteelliseksi väitöskirjaksi edustava, ja tekstiä on miellyttävää lukea. Taulukoita ja kaavioita on selkeytetty käyttämällä rohkeasti värejä.

Teos ei kuulu mihinkään tieteelliseen sarjaan. Tällä tuskin on merkitystä teoksen tunnettuuden kannalta, koska valtaosa tutkijoista hakee joka tapauksessa aineistonsa verkosta aiheen perusteella eivätkä tieteelliset kustantajat ole kovin aktiivisia markkinoimaan julkaisujaan. Kansainvälisen tutkijayhteisön kannalta suurempi ongelma lienee se, että teos on suomenkielinen. Junttila on itsekin tuonut kielimuurin merkityksen esiin useissa kohdin (esim. s. 34, 40$41,121,229)$. Toisaalta mikään ei estä julkaisemasta parhaita paloja myöhemmin muilla kielillä.

Villin näköinen kansikuva tuo ensi vilkaisulla mieleen pakanalliset orgiat, mutta tarkempi tutkiminen paljastaa sen tieteellisen taustan. Kuvaan on koottu suuri määrä sellaisia reaalimaailman tarkoitteita, joiden nimityksille on esitetty balttilaisia lainaetymologioita. On hanhi, hirvi, kantele, morsian, perkele, reki, tuura ja paljon muuta. Kuvan on piirtänyt tutkijakollega Rigina Ajanki.

\section{Arvokasta perustutkimusta}

Pienistä puutteistaan huolimatta Junttilan työ on poikkeuksellisen ansiokas ja tutkijayhteisön kannalta hyödyllinen väi- töskirja. Siinä esitellään yli tuhat sellaista sanaa, jotka ainakin kerran on pyritty selittämään itämerensuomalaisten kielten vanhoihin balttilaislainoihin kuuluvaksi. Työn lopussa Junttila kuitenkin toteaa, että varmojen lainojen määrä on alle kolmesataa ja tuskin nouseekaan sen yli, vaikka uusimpien metodien puitteissa vielä voitaisiinkin osoittaa kymmeniä lainoja lisää.

Junttilan väitöskirja on teos, jota kukaan itämerensuomen sanaston tutkija ei vastedes voi ohittaa. Tieteellisen mielenkiinnon lisäksi se herättää myös inhimillistä uteliaisuutta, sillä sitä voi lukea lainasanatutkijoiden henkilökohtaisten saavutusten arviointina. Kuka on esittänyt eniten balttilaisia lainaetymologioita? Kenen etymologiat ovat saaneet eniten kannatusta? Kenen etymologioista suurin osa on vaiettu kuoliaaksi? Vastaukset löytyvät Junttilan väitöskirjasta. Ottakaa ja lukekaa!

\section{KAISA HÄKKINEN etunimi.sukunimi@utu.fi}

\section{Lähteet}

Hakulinen, LAuri 1979: Suomen kielen rakenne ja kehitys. Neljäs, korjattu ja lisätty painos. Helsinki: Otava.

Karlsson, Fred 1975: Fennistiikan tieteenparadigmasta ja sen ohjausvaikutuksesta. - Virittäjä 79 s. 179-192.

Kunn, Tномаs S. 1970: The structure of scientific revolutions. Toinen laitos. London: The University of Chicago Press.

Salminen, Timo 2008: Aatteen tiede. Suomalais-Ugrilainen Seura 1883-2008. Suomalaisen Kirjallisuuden Seuran Toimituksia 1172. Helsinki: Suomalaisen Kirjallisuuden Seura.

Thomsen, Vilh. 189o: Beröringer mellem de finske og de baltiske (litauisk-lettiske) Sprog: En sproghistorisk Undersøgelse. København: Bianco Lunos Kgl. HofBogtrykkeri. 
Thomsen, Wilh. 1870: Über den einfluss der germanischen sprachen auf die finnischlappische. Eine sprachgeschichtliche unter- suchung. Halle: Verlag der Buchhand-

lung des Waisenhauses.

\section{Kielipolitiikan analyysia viittomakielten näkökulmasta}

\begin{abstract}
Maartje De Meulder: The power of language policy. The legal recognition of sign languages and the aspirations of deaf communities. Jyväskylä Studies in Humanities 301. Jyväskylä: Jyväskylän yliopisto 2016. Yhteenveto-osuus 134 s. ja viisi artikkelia. ISBN 978-951-39-6875-5.
\end{abstract}

Suomalaisesta viittomakielestä on tehty tutkimusta runsaat 30 vuotta, ja viittomakielen väitöskirjoja on Suomessa ilmestynyt viimeisten 15 vuoden aikana tasaiseen tahtiin. Ensimmäinen väitöskirja oli Ritva Takkisen (2002) tutkimus viittomakielisten lasten käsimuotojen omaksumisesta. Tutkimuksissa on käsitelty pääosin fonologiaa ja jonkin verran morfologiaa, ja jossain määrin tarkastelu on laajentunut myös syntaksin suuntaan (ks. Jantunen 2009). Sosio-onomastista tutkimusta edustaa Päivi Rainòn (2004) väitöskirja suomalaisen viittomakielen henkilöviittomien piirteistä. Teoksessa on myös tietoa Suomen viittomakielisen yhteisön ja suomalaisen viittomakielen alkuvaiheista. Kielisosiologista lähestymistapaa edustaa Karin Hoyerin väitöskirja (2012), jossa tarkastellaan kielisuunnittelua suomenruotsalaisen, albanialaisen ja kosovolaisen viittomakielen sanakirjatyön näkökulmasta. Kaikkiaan sanakirjatyö on ollut tärkeä osa viittomakielisten palvelujen parantamista ja viittomakielen näkyväksi tekemistä niin Suomessa kuin muuallakin. Suomalaisesta ja suomenruotsalaisesta viittomakielestä ylläpidetään Kuurojen Liitossa kahta avointa ja ilmaista sanakirjapalvelua, Suomen viittomakielten verkkosanakirjaa
Suvi ja Suomalaisen viittomakielen wikisanakirjaa. Paljon työtä on siis tehty, mutta paljon on vielä tehtävääkin.

Kielipolitiikka on aina ollut muodossa tai toisessa keskeinen osa politiikkaa, mutta määrätietoisemmin kielipolitiikan tutkimusta on harjoitettu parin kolmen viime vuosikymmenen ajan. Tällä kentällä on liikkunut eri perinteistä nousevia tutkijoita. Osa heistä on lähestynyt kielipolitiikan kysymyksiä teoreettisemmin, kun taas toiset ovat keskittyneet enemmän kielipolitiikan toimeenpanoon ja käytännön tilanteisiin eri kieliyhteisöissä. Myös viittomakielten tilannetta on aiempaa enemmän analysoitu viime vuosikymmenten aikana. Tässä työssä ovat kohdanneet monet tieteenalat, kuten sosiologia ja muut yhteiskuntatieteet, kielitiede ja historia. Esimerkiksi Karin Hoyer (2012), Rachel McKee (2011), Joseph J. Murray (2015), Trevor Reagan (2010) ja Tove Skutnabb-Kangas (ks. SkutnabbKangas \& Aikio-Puoskari 2003) ovat käsitelleet viittomakielisten kielellisiä oikeuksia ja viittomakielten elinmahdollisuuksia eri ympäristöissä. Maartje De Meulderin väitöskirja The power of language policy: The legal recognition of sign languages and the aspirations of deaf communities on osa tätä tutkimusten ketjua ja tuo siihen merkittävän lisän.

\section{Tutkimuksen tavoitteet, tutkimuskysymykset ja menetelmät}

De Meulderin tutkimus on ensimmäinen Suomessa julkaistu väitöskirjatasoinen 